\title{
Aggregation-enhanced emission (AEE)-active polyamides with methylsulfonyltriphenylamine units for electrofluorochromic applications
}

\author{
Ningwei Sun ${ }^{a, 1}$, Ziwei Zhou ${ }^{b, 1}$, Shiyao Meng ${ }^{a}$, Danming Chao ${ }^{a}$, Xiaojing Chu ${ }^{c}$, \\ Xiaogang Zhao ${ }^{\text {a, }}$, Daming Wang ${ }^{a}$, Hongwei Zhou ${ }^{a}$, Chunhai Chen ${ }^{a}$ \\ a Alan G. MacDiarmid Institute, College of Chemistry, Jilin University, Changchun 130012, PR China \\ b State Key Laboratory of Supramolecular Structure and Materials, College of Chemistry, Jilin University, Changchun 130012, PR China \\ ${ }^{\mathrm{c}}$ Key Laboratory of Coastal Environmental Processes and Ecological Remediation, Yantai Institute of Coastal Zone Research, Chinese Academy of Science, \\ Yantai 264100, PR China
}

\section{A R T I C L E I N F O}

\section{Article history:}

Received 16 December 2016

Received in revised form

22 January 2017

Accepted 23 January 2017

Available online 24 February 2017

\section{Keywords:}

Triphenylamine

Sulfone

Polyamide

Electrochromism

Electrofluorochromism

\begin{abstract}
A B S T R A C T
In this work, a series of AEE-active polyamides containing methylsulfonyltriphenylamine units were prepared from a newly synthesized diamine " $4,4^{\prime}$-diamine- 4 "-methylsulfonyltriphenylamine" and three dicarboxylic acids, which were highly soluble in various organic solvents and exhibited outstanding thermostability. The resulting polymer films showed one reversible redox couple along with apparent color changing from colorless to purple. The polymer solutions revealed relatively weak fluorescence with quantum yields in the range of $2.2-26.2 \%$, which could be enhanced by induced aggregation in poor solvents. Furthermore, the bright fluorescence of the solid polymer film could be reversibly tuned by direct electrochemical redox of triphenylamine with a high contrast ratio $\left(I_{\text {off }} / I_{\text {on }}\right)$ of 234 . Overall, this comprehensive investigation of their interesting electrochromic and electrofluorochromic bifunctional properties not only supplies a deep understanding of the optical essence upon electrical stimuli but also paves the way for their future intelligent applications.
\end{abstract}

๑) 2017 Elsevier Ltd. All rights reserved.

\section{Introduction}

Recently, stimuli-responsive fluorescent materials have attracted intense interest due to their potential applications in sensors and displays [1-4]. In particular, a promising approach to achieve reversible fluorescence switching is based on the conversion of the redox states driven by electrical stimuli, which is known as electrofluorochromism [5-7]. In view of the fascinating advantages and wide application foreground, several efforts have been made to exploit various electrofluorochromic materials, mainly including dyads and electroactive fluorophores [8-13]. Specially, the latter ones behave more attractive since their fluorescence could be switched by electrochemical modulation directly and readily. To further meet the requirement of commercial application, some parameters such as rapid response time, high contrast ratio and

\footnotetext{
* Corresponding author.

E-mail address: xiaogang@jlu.edu.cn (X. Zhao).

1 N.W. Sun and Z.W. Zhou contributed to this work equally.
}

long term stability are crucial for high performance electrofluorochromic materials. However, most of the existing materials could not achieve all these demands at the same time, especially lack of high contrast due to their poor fluorescence essence. To better satisfy the future optoelectronic applications, more versatile materials are urgent to be further exploited.

Triphenylamine (TPA) with special starburst structure has been widely applied in various optoelectronic materials such as organic light emitting diodes (OLEDs), dye-sensitized solar cells (DSSCs) and polymer memory devices, owing to its strong electrondonating and transporting capability [14-19]. Moreover, the TPA derivatives always yield obvious changes in color during the oxidation process, and thus have been developed as attractive anodic electrochromic materials [20-25]. In addition, para-protective TPA has also been demonstrated an ideal electro-switching modulator for its stable electroactivity by effectively preventing coupling reaction [26,27]; several reported fluorescent TPA derivatives exhibited interesting electrochemical fluorescence switching behaviors [28-30]. However, the aggregation-caused quenching (ACQ) essence of most of these materials resulted in 
weak fluorescence in the solid states, which greatly decreased the fluorescence "on/off" sensitivity. To address this problem, the opposite of ACQ aggregation-induced emission (AIE) effect which was first reported by Tang [31] paves a facile way for the design and synthesis of efficient solid-state materials. Remarkably, sulfonecontaining materials are receiving increasing attention due to their effectively enhanced photoluminescence quantum yields $[32,33]$. Adachi and coworkers have reported amount of TPAsulfone derivatives with interesting thermal activated delayed fluorescence (TADF) properties, ascribed to the small energy gap between the lowest single $\left(\mathrm{S}_{1}\right)$ and the lowest triplet $\left(\mathrm{T}_{1}\right)$ states resulting in strong reverse intersystem crossing (RISC) process [34-37]. Lee et al. reported several donor-acceptor molecules with high-efficiency blue light-emitting based on sulfone as acceptor $[38,39]$. In view of the propeller-like structure and electrondonating characteristic of TPA as well as the enhanced fluorescence and electron-withdrawing properties of sulfone unit, TPAsulfone derivatives may readily act as electro and AIE-active modulators in electro-switching system, which will greatly promote the development of electrochromic and electrofluorochromic materials.

In this work, we herein report the synthesis of a new diamine monomer, "4,4'-diamine-4"-methylsulfonyltriphenylamine", and its derived electroactive polyamides. Their properties such as organic solubility, thermal stability, AEE fluorescence, redox, electrochromic and electrofluorochromic performances are also disclosed and investigated in detail.

\section{Experimental section}

\subsection{Materials}

4-Methylsulfonylaniline (TCI), 4-fluoronitrobenzene (Acros), cesium fluoride (CsF, Acros), 10\% palladium on charcoal (Pd/C, TCI), hydrazine monohydrate (TCI), triphenyl phosphite (TPP, Acros) were used as received. The model compound with aliphatic structure was synthesized and characterized as described in the supporting information. Calcium chloride was dried under vacuum at $180{ }^{\circ} \mathrm{C}$ for $20 \mathrm{~h}$ prior to use. $\mathrm{N}$-methyl-2-pyrrolidinone (NMP) and dimethyl sulfoxide (DMSO) were dried using 4 Å molecular sieves prior to use. Tetrabutylammonium perchlorate (TBAP, Acros) was recrystallized twice from ethanol under nitrogen atmosphere and then dried under vacuum at $40{ }^{\circ} \mathrm{C}$ before use. Commercially available dicarboxylic acids that include trans-1,4Cyclohexanedicarboxylic acid (3a, TCI), 4,4'-dicarboxydiphenylether (3b, TCI) and 2,2-bis(4-carboxy-phenyl)hexafluoropropane $(3 \mathrm{c}, \mathrm{TCI})$ were dried under vacuum at $100^{\circ} \mathrm{C}$ prior to use. Other commercially available chemicals and solvents were used without further purification.

\subsection{Synthesis of 4,4'-dinitro-4"-methylsulfonyltriphenylamine}

In a $250 \mathrm{~mL}$ round-bottom flask equipped with a stirring bar, a mixture of $12.0 \mathrm{~g}$ (70.2 mmol) of 4-Methylfulfonylaniline, $20.8 \mathrm{~g}$ (147.4 mmol) of 4-fluoronitrobenzene and $22.4 \mathrm{~g}(147.4 \mathrm{mmol})$ of CsF in $130 \mathrm{~mL}$ of DMSO was heated under nitrogen atmosphere at $165{ }^{\circ} \mathrm{C}$ for $24 \mathrm{~h}$. After cooling to room temperature, the reaction solution was poured into $500 \mathrm{~mL}$ of ethanol to form yellow crude which was subsequently washed thoroughly by hot water and ethanol. Then the crude was recrystallized from DMF/ethanol, yielding $24.1 \mathrm{~g}$ of the desired dinitro compound in $83.1 \%$ with a melting point of $271{ }^{\circ} \mathrm{C}$. FT-IR ( $\left.\mathrm{KBr}\right): 1307 \mathrm{~cm}^{-1}, 1578 \mathrm{~cm}^{-1}\left(-\mathrm{NO}_{2}\right.$ stretch). ${ }^{1} \mathrm{H}$ NMR (300 MHz, DMSO- $\left.d_{6}, \delta, \mathrm{ppm}\right): 8.24(\mathrm{~d}, J=9.2 \mathrm{~Hz}$, $4 \mathrm{H}), 7.97(\mathrm{~d}, J=8.9 \mathrm{~Hz}, 2 \mathrm{H}), 7.43(\mathrm{~d}, J=8.9 \mathrm{~Hz}, 2 \mathrm{H}), 7.31(\mathrm{~d}$, $J=9.2 \mathrm{~Hz}, 4 \mathrm{H}), 3.27(\mathrm{~s}, 3 \mathrm{H})$.

\subsection{Synthesis of $4,4^{\prime}$-diamino-4" -methylsulfonyltriphenylamine}

In a $500 \mathrm{~mL}$ round-bottom flask, $15 \mathrm{~g}(8.8 \mathrm{mmol})$ of the dinitro compound 1 and $1.5 \mathrm{~g}$ of $\mathrm{Pd} / \mathrm{C}$ were dispersed in $70 \mathrm{~mL}$ of ethanol. After heating the mixture to reflux, $8.4 \mathrm{~g}$ hydrazine monohydrate was added slowly into the react system. Then the mixture was stirred at the reflux temperature for $8 \mathrm{~h}$. The $\mathrm{Pd} / \mathrm{C}$ was removed by filtration and the resulting filtrate was cooled under a nitrogen flow to grow light-yellow crystals. Then the crystals were collected and dried under vaccum $\left(11.0 \mathrm{~g}, 86.1 \%\right.$ of yield, $\left.\mathrm{mp}=235^{\circ} \mathrm{C}\right) .{ }^{1} \mathrm{H}$ NMR (300 MHz, DMSO- $\left.d_{6}, \delta, \mathrm{ppm}\right): 7.54\left(\mathrm{~d}, J=9.0 \mathrm{~Hz}, 2 \mathrm{H}, \mathrm{H}_{\mathrm{d}}\right), 6.93$ (d, $\left.J=8.6 \mathrm{~Hz}, 4 \mathrm{H}, \mathrm{H}_{\mathrm{b}}\right), 6.65-6.48\left(\mathrm{~m}, 6 \mathrm{H}, \mathrm{H}_{\mathrm{c}}+\mathrm{H}_{\mathrm{a}}\right), 5.17\left(\mathrm{~s}, 4 \mathrm{H},-\mathrm{NH}_{2}\right)$, $3.05\left(\mathrm{~s}, 3 \mathrm{H},-\mathrm{CH}_{3}\right) .{ }^{13} \mathrm{C}$ NMR $\left(75 \mathrm{MHz}\right.$, DMSO- $\left.d_{6}, \delta, \mathrm{ppm}\right): 153.58$, 146.97, 133.86, 128.32, 128.08, 127.29, 114.90, 113.70, 44.35.

\subsection{Synthesis of polyamides}

A series of polyamides were prepared via polycondensation (as shown in Scheme 2) [40]. The prepared polyamides were abbreviated to $4 \mathrm{a}, 4 \mathrm{~b}$ and $4 \mathrm{c}$, respectively. In a typical procedure, a mixture of $0.353 \mathrm{~g}$ ( $1 \mathrm{mmol}$ ) of the diamine monomer $2,0.172 \mathrm{~g}$ $(1 \mathrm{mmol})$ of $3 \mathrm{a}, 0.12 \mathrm{~g}$ of calcium chloride, $1 \mathrm{~mL}$ of triphenyl phosphite, $0.5 \mathrm{~mL}$ of pyridine, and $2.5 \mathrm{~mL}$ of NMP was heated with stirring at $120{ }^{\circ} \mathrm{C}$ for $3 \mathrm{~h}$. After cooling to room temperature, the obtained viscous polymer solution was poured slowly into $250 \mathrm{~mL}$ of methanol, producing a stringy, fiber-like precipitate. The resulting polymer was washed thoroughly with hot water and methanol, and then reprecipitated by DMAc/ethanol twice for further purification. The ${ }^{1} \mathrm{H}$ NMR data of these polyamides are listed as follows.

Polyamide 4a: ${ }^{1} \mathrm{H}$ NMR (300 MHz, DMSO- $\left.d_{6}, \delta, \mathrm{ppm}\right): 9.98$ (s, $2 \mathrm{H}), 8.02-7.45(\mathrm{~m}, 6 \mathrm{H}), 7.14(\mathrm{~d}, J=8.4 \mathrm{~Hz}, 4 \mathrm{H}), 6.83(\mathrm{~d}, J=8.6 \mathrm{~Hz}$, $2 \mathrm{H}), 3.11(\mathrm{~s}, 3 \mathrm{H}), 2.44-2.24(\mathrm{~m}, 2 \mathrm{H}), 2.02-1.81(\mathrm{~m}, 4 \mathrm{H}), 1.60-1.38$ $(\mathrm{m}, 4 \mathrm{H})$

Polyamide 4b: ${ }^{1} \mathrm{H}$ NMR (300 MHz, DMSO- $d_{6}, \delta$, ppm): 10.34 (s, $2 \mathrm{H}), 8.06(\mathrm{~d}, J=8.4 \mathrm{~Hz}, 4 \mathrm{H}), 7.84(\mathrm{~d}, J=8.7 \mathrm{~Hz}, 4 \mathrm{H}), 7.70(\mathrm{~d}$, $J=8.9 \mathrm{~Hz}, 2 \mathrm{H}), 7.31-7.12(\mathrm{~d}, J=8.4 \mathrm{~Hz}, 6 \mathrm{H}), 6.91(\mathrm{~d}, J=8.7 \mathrm{~Hz}, 2 \mathrm{H})$, $3.12(\mathrm{~s}, 3 \mathrm{H})$.

Polyamide 4c: ${ }^{1} \mathrm{H}$ NMR (300 MHz, DMSO- $\left.d_{6}, \delta, \mathrm{ppm}\right): 10.53$ (s, $2 \mathrm{H}), 8.05(\mathrm{~d}, J=8.4 \mathrm{~Hz}, 4 \mathrm{H}), 7.83(\mathrm{~d}, J=8.6 \mathrm{~Hz}, 4 \mathrm{H}), 7.70(\mathrm{~d}$, $J=8.8 \mathrm{~Hz}, 2 \mathrm{H}), 7.54(\mathrm{~d}, J=7.9 \mathrm{~Hz}, 4 \mathrm{H}), 7.22(\mathrm{~d}, J=8.6 \mathrm{~Hz}, 4 \mathrm{H}), 6.92$ $(\mathrm{d}, J=8.8 \mathrm{~Hz}, 2 \mathrm{H}), 3.12(\mathrm{~s}, 3 \mathrm{H})$.

The polyamide films were prepared via solution casting. $0.3 \mathrm{~g}$ of sample was dissolved in $6 \mathrm{~mL}$ of DMAc to form the homogeneous solution, which was then poured into a $6 \mathrm{~cm}$ glass Petri dish and placed in the oven at $90{ }^{\circ} \mathrm{C}$ for $12 \mathrm{~h}$ to release the solvent slowly. After that, the damp-dry film was further dried at $160{ }^{\circ} \mathrm{C}$ for $12 \mathrm{~h}$ under vacuum. These as-prepared films were about $30-40 \mu \mathrm{m}$ in thickness and were subsequently used for solubility tests and thermal analyses.

\subsection{Measurements}

Fourier transform infrared (FT-IR) spectra were recorded through a Bruker Vector 22 spectrometer at a resolution of $4 \mathrm{~cm}^{-1}$ in the range of $400-4000 \mathrm{~cm}^{-1}$. Nuclear magnetic resonance (NMR) spectra were determined on a BRUKER-300 spectrometer at $300 \mathrm{MHz}$ for ${ }^{1} \mathrm{H}$ NMR and $75 \mathrm{MHz}$ for ${ }^{13} \mathrm{C}$ NMR in deuterated DMSO. Inherent viscosities $\left(\eta_{\text {inh }}\right)$ were measured through an Ubbelohde viscometer with a $0.5 \mathrm{~g} / \mathrm{dL}$ of DMAc solution at $25{ }^{\circ} \mathrm{C}$. Weightaverage molecular weight $\left(M_{\mathrm{w}}\right)$ and number-average molecular weights $\left(M_{\mathrm{n}}\right)$ were obtained via gel permeation chromatographic (GPC) analysis on the basis of polystyrene calibration on a PL-GPV 220 instrument with DMF as an eluent at a flow rate of $1.0 \mathrm{~mL} /$ min. Differential scanning calorimetric (DSC) analysis was 


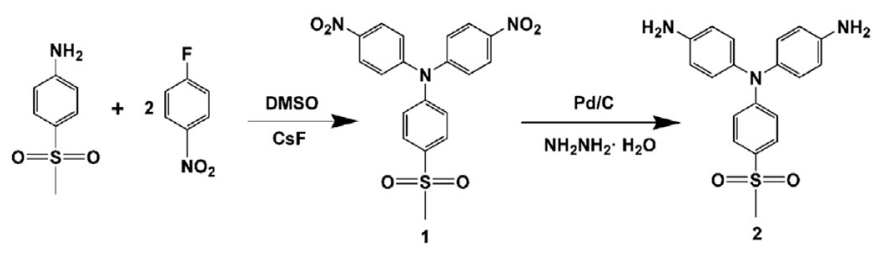

Scheme 1. Synthetic route to the diamine 2.

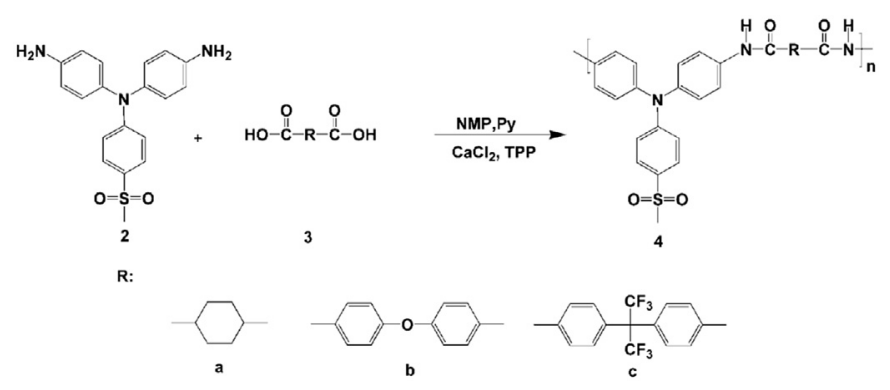

Scheme 2. Synthesis of the polyamides.

performed on a TA instrument DSC Q100 at a scanning rate of $10^{\circ} \mathrm{C} /$ min in a nitrogen flow of $50 \mathrm{~mL} / \mathrm{min}$. Thermogravimetric analysis (TGA) was conducted with the TA 2050 , with a heating rate of $10^{\circ} \mathrm{C} /$ min under nitrogen atmosphere. Electrochemistry measurements were carried out on a $\mathrm{CHI}$ 660e electrochemical analyzer. Cyclic voltammetry (CV) was conducted by using a three-electrode cell. The working electrode was prepared by drop-coating of the polymer solutions onto an ITO glass substrate (the area of polymer films was about $0.5 \times 2 \mathrm{~cm}^{2}$ ). A platinum wire was used as an auxiliary electrode and a homemade $\mathrm{Ag} / \mathrm{AgCl}, \mathrm{KCl}$ (sat.) was used as a reference electrode. Ultraviolet-visible (UV-vis) spectra were measured using a Shimadzu UV 3101-PC spectrophotometer. Photoluminescence (PL) spectra and fluorescent quantum yield were determinate with an Edinburgh FLS920 fluorescence spectrophotometer. Fluorescence quantum yield $\left(\Phi_{\mathrm{F}}\right)$ was determined using a calibrated integrating sphere.

\section{Results and discussion}

\subsection{Monomers and polyamides synthesis}

As shown in Scheme 1, the new diamine 2 with methylsulfonyltriphenylamine unit was synthesized via a two-step route; the diamine was successfully synthesized by $\mathrm{Pd} / \mathrm{C}$-catalyzed reduction of the dinitro 1 which was resulted from the nucleophilic displacement reaction of 4-methylfulfonylaniline with 4-fluoronitrobenzene. The structures of the dinitro and diamine compounds were analyzed and confirmed by FT-IR and NMR techniques. The characteristic bands of nitro groups at around 1578 and $1307 \mathrm{~cm}^{-1}$ disappeared after the reduction reaction. Meanwhile, typical $\mathrm{N}-\mathrm{H}$ stretching absorptions pairs corresponding to the amino group appeared in the region of $3300-3500 \mathrm{~cm}^{-1}$, indicating the formation of the new diamine (Fig. S1). Furthermore, the ${ }^{1} \mathrm{H}$ NMR spectrum of the diamine monomer 2 with the assignments for proton signals was illustrated in Fig. 1a, which further supports that the target diamine monomer with methylsulfonyltriphenylamine unit has been synthesized successfully.

A series of polyamides (4a-4c) were prepared from the diamine 2 with three different dicarboxylic acids through the phosphorylation technique. All the polymerization processes were homogeneously and afforded highly viscous polymer solutions after $3 \mathrm{~h}$. The inherent viscosities of these polyamides ranged from 0.87 to $1.25 \mathrm{dL} / \mathrm{g}$ and the GPC measurement showed the number-average molecular weights $\left(M_{\mathrm{n}} \mathrm{s}\right)$ of $41200-69600$ (Table S1). All these high-molecular-weight polyamides could be solution-casted into free-standing films. The typical FTIR spectrum of polyamide $4 \mathrm{a}$ is illustrated in Fig. S2, which exhibited the characteristic absorption bands of 1666 and $3321 \mathrm{~cm}^{-1}$. The proposed structures of these polyamides were also confirmed by ${ }^{1} \mathrm{H}$ NMR spectra with amide resonance peaks appearing at around 9.9-10.6 ppm (Fig. 1b).

\subsection{Solubility and thermal properties}

The solubility tests of these polyamides were studied by dissolving $10 \mathrm{mg}$ sample in $1 \mathrm{~mL}$ organic solvents (Table S1). The series of polyamides exhibited excellent solubility in polar solvents, which is greatly beneficial for the fabrication of large-scale thin film devices. The thermal properties of these polyamides were investigated by TGA and DSC measurements, with the results summarized in Table 1. During the decomposition processes in the TGA curves (Fig. S3), the $10 \%$ weight loss temperatures in nitrogen atmospheres were recorded in the range of $443-470{ }^{\circ} \mathrm{C}$, and the carbonized residue was over $44 \%$ at $800{ }^{\circ} \mathrm{C}$. The glass transition temperatures were observed at $306-334{ }^{\circ} \mathrm{C}$ depending on the stiffness of polymer structure. Thus, the excellent thermal properties of these polyamides will certainly contribute to extending their service time in optoelectronic devices.

\subsection{Optical properties}

The optical properties of these polyamides were examined with the detail spectroscopic data summarized in Table 2. The absorption maxima of these polyamides were located at $309-338 \mathrm{~nm}$ in NMP
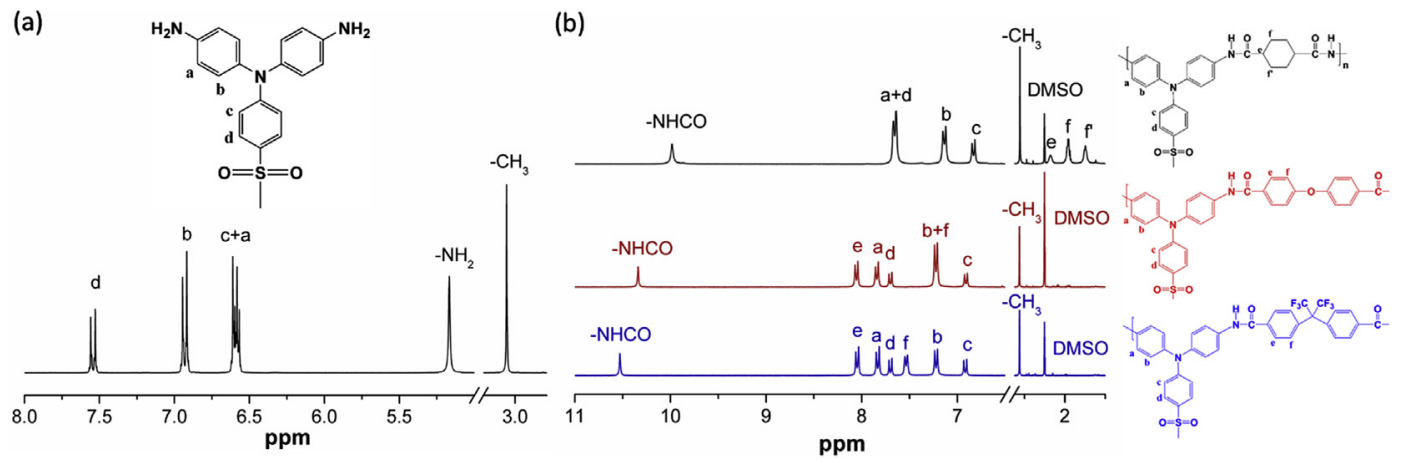

Fig. 1. ${ }^{1} \mathrm{H}$ NMR spectra of diamine 2 (a) and polyamides $4 \mathrm{a}-4 \mathrm{c}(\mathrm{b})$ in DMSO- $d_{6}$. 
Table 1

Thermal properties of the polyamides.

\begin{tabular}{llll}
\hline Polymer & $T_{\mathrm{g}}{ }^{\mathrm{a}}\left({ }^{\circ} \mathrm{C}\right)$ & $T_{\mathrm{d} 10 \%}{ }^{\mathrm{b}}\left({ }^{\circ} \mathrm{C}\right)$ & Char yield $(\mathrm{wt} \%)^{\mathrm{c}}$ \\
\hline 4a & 330 & 443 & 44 \\
4b & 306 & 470 & 63 \\
4c & 334 & 456 & 57 \\
\hline
\end{tabular}

${ }^{\text {a }}$ Obtained at the baseline shift in the second heating DSC traces, with a heating rate of $10{ }^{\circ} \mathrm{C} / \mathrm{min}$ under nitrogen atmosphere.

b Decomposition temperature at which a $10 \%$ weight loss was recorded via TGA at a heating rate of $10^{\circ} \mathrm{C} / \mathrm{min}$.

${ }^{\mathrm{c}}$ Residual weight percentage at $800{ }^{\circ} \mathrm{C}$ in nitrogen atmosphere.

solutions and 312-344 $\mathrm{nm}$ in solid films, respectively, due to the $\pi$ $\pi^{*}$ transition of methylsulfonyltriphenylamine moieties. The dilute NMP solutions of these polyamides showed fluorescence maxima at $485-488 \mathrm{~nm}$ with quantum yields of $2.2-26.2 \%$ (Fig. 2a). Compared with the polyamide $4 \mathrm{~b}$ and $4 \mathrm{c}$, the high fluorescence of polyamide 4a could be ascribed to its reduced charge-transfer effect between TPA donor and benzamide acceptor [28]. Moreover, these polyamide films revealed enhanced fluorescence with quantum yields increasing to $2.7-32.1 \%$. To further confirm the AEE effect, water, as the poor solvent for the polyamides, was added into the NMP solutions of polyamide 4a and different percentages of NMPwater mixtures were examined by fluorescence spectroscopy (Fig. 2b). In pure NMP solution, the polyamide 4a exhibited yellowish-green emission with a maximum peak at around $490 \mathrm{~nm}$. With increasing water fractions from 0 to $50 \%$, during which the polyamide aggregated to particles, the emission spectra were blueshifted and the fluorescence intensity enhanced. The restriction of intramolecular rotations resulted in the higher fluorescence intensity [41]. By further increasing water fractions, however, the fluorescence intensity decreased gradually with a slight red-shift, which could be explained by the fact that the more increasing aggregation led to the enhanced intermolecular stack. These fluorescence spectra changes could be explained by the competition of ACQ and AEE effects. In addition, it is well known that the materials containing donor-acceptor structures are expected to show solvatochromic behaviors. To better demonstrate the solvatochromic properties, the model compound of polyamide 4a which has better solubility was investigated in various solvents with different polarity. Fig. 2c and d exhibited the normalized UV-vis and PL spectra of the model compound in different solvents. All the absorption spectra were similar without obvious shift in the peak maximum, indicating the little effect of the solvent polarity on the groundstate electronic transition. However, the emission spectra revealed strong dependence of solvent polarity; in low-polar toluene, the model compound emitted strong blue light, while in the high-polar solvent DMSO, the emission color became yellow. A dramatic bathochromic shift of the emission peak from 445 to
$501 \mathrm{~nm}$ was recorded with the changes of solvent polarity and this phenomenon could be ascribed to the fast inter-conversion process from the emissive excited state to the low emissive state [42].

\subsection{Electrochemical and electrochromic properties}

The redox behavior of these polyamides was investigated by CV measurement in a three-electrode cell with a polyamide-coated ITO electrode as the working electrode, a Pt wire as the counter electrode and an $\mathrm{Ag} / \mathrm{AgCl}$ electrode as the reference electrode. As shown in Fig. 3, the polyamide $4 a-4 c$ all exhibited one reversible redox couple with onset potentials of the oxidation process ranging from 0.88 to $0.91 \mathrm{~V}$, which indicates that the structures of dicarboxylic acid have a weak influence on the oxidation of triphenylamine core. On the basis of their onset oxidation potentials and ferrocene/ferrocenium reference, the highest occupied molecular orbital (HOMO) levels of these polyamides were estimated to be $5.26-5.29 \mathrm{eV}$. The bandgaps $\left(E_{\mathrm{g}}\right)$, as determined from $\lambda_{\text {onset }}$ of the polyamide films, lay between 3.11 and $3.20 \mathrm{eV}$. Thus, the corresponding lowest unoccupied molecular orbital (LUMO) levels were calculated to be $2.06-2.18 \mathrm{eV}\left(\mathrm{LUMO}=\mathrm{HOMO}-E_{\mathrm{g}}\right)$. All the details of electrochemical data as well as HOMO and LUMO levels are summarized in Table 2.

Considering the phenomenon that the polymer films coated on ITO substrates were observed to switch their appearance colors between colorless and purple reversibly, spectroelectrochemical measurements were performed to compare the optical properties of polyamide 4a at different applied potentials (Fig. 4A). Upon the electro-oxidation steadily arising from $0.0 \mathrm{~V}$ to $1.2 \mathrm{~V}$, the intensity of the characteristic absorption peak at $312 \mathrm{~nm}$ for the neutral form of the polyamide decreased gradually, while three new peaks at 388,545 and $854 \mathrm{~nm}$ grew up. The spectra changes were ascribed to the formation of a monocation radical, which caused the TPA structure to flatten off and absorb long wave lights.

Electrochromic switching studies were also performed through square-wave potential stepping experiments with the transmittance change at the given wavelength monitored as a function of time. The typical switching behavior of polyamide 4a with a cycle time of $10 \mathrm{~s}$ was depicted in Fig. 4B. After 50 cycles, no obvious spectral decay was observed, indicating the highly stability as electrochromic device. The switching time plays an imperative role in electrochromic applications, and here, it was calculated as $90 \%$ of the time taken for the full switching state. The polyamide $4 \mathrm{a}$ revealed a satisfactory switching time of $4.1 / 1.0 \mathrm{~s}$ for coloring/ blenching process. In addition, coloration efficiency (CE) is also an important parameter of electrochromic materials, and it was defined as: $C E=\Delta \mathrm{A} / \mathrm{Q}_{\mathrm{d}}\left(\Delta \mathrm{A}\right.$ : optical absorbance change; $\mathrm{Q}_{\mathrm{d}}$ : injected/ejected charge per unit sample area during a redox step). The CE value of polyamide 4a ranged from $121 \mathrm{~cm}^{2} \mathrm{C}^{-1}$ for the first

Table 2

Optical and electrochemical properties of the polyamides.

\begin{tabular}{|c|c|c|c|c|c|c|c|c|c|c|c|c|}
\hline \multirow[t]{2}{*}{ Polymer } & \multicolumn{3}{|c|}{ Solution $(\mathrm{nm})^{\mathrm{a}}$} & \multicolumn{4}{|l|}{ Film (nm) } & \multicolumn{2}{|c|}{$\begin{array}{l}\text { Oxidation } \\
\text { Potential (V) }\end{array}$} & \multirow[t]{2}{*}{$E_{\mathrm{g}}{ }^{\mathrm{d}}$} & \multirow[t]{2}{*}{$\mathrm{HOMO}^{\mathrm{e}}$} & \multirow[t]{2}{*}{ LUMO $^{f}$} \\
\hline & Abs. max & PL max & $\overline{\Phi_{\mathrm{F}}(\%)^{\mathrm{c}}}$ & Abs. onset & Abs. max & PL max & $\overline{\Phi_{\mathrm{F}}(\%)^{\mathrm{b}}}$ & $E_{\text {onset }}$ & $\overline{E_{1 / 2}{ }^{c}}$ & & & \\
\hline $4 a$ & 309 & 488 & 26.2 & 387 & 312 & 474 & 32.1 & 0.88 & 0.97 & 3.20 & 5.26 & 2.06 \\
\hline $4 b$ & 332 & 486 & 4.0 & 397 & 336 & 478 & 5.7 & 0.89 & 1.00 & 3.12 & 5.27 & 2.15 \\
\hline $4 c$ & 338 & 485 & 2.2 & 398 & 344 & 482 & 2.7 & 0.91 & 1.02 & 3.11 & 5.29 & 2.18 \\
\hline
\end{tabular}

a The polymer concentration was $1 \times 10^{-5} \mathrm{~mol} / \mathrm{L}$ in NMP.

b The quantum yield was tested by using a calibrated integrating sphere.

c Average potential of the redox couple peaks.

d The data were calculated by the equation: $E_{\mathrm{g}}=1240 / \lambda_{\text {onset }}$ (energy gap between HOMO and LUMO).

e The HOMO energy levels were calculated from cyclic voltammetry and were referenced to ferrocene $(4.8 \mathrm{eV})$.

${ }^{\mathrm{f}} \mathrm{LUMO}=$ HOMO- $E_{\mathrm{g}}$. 

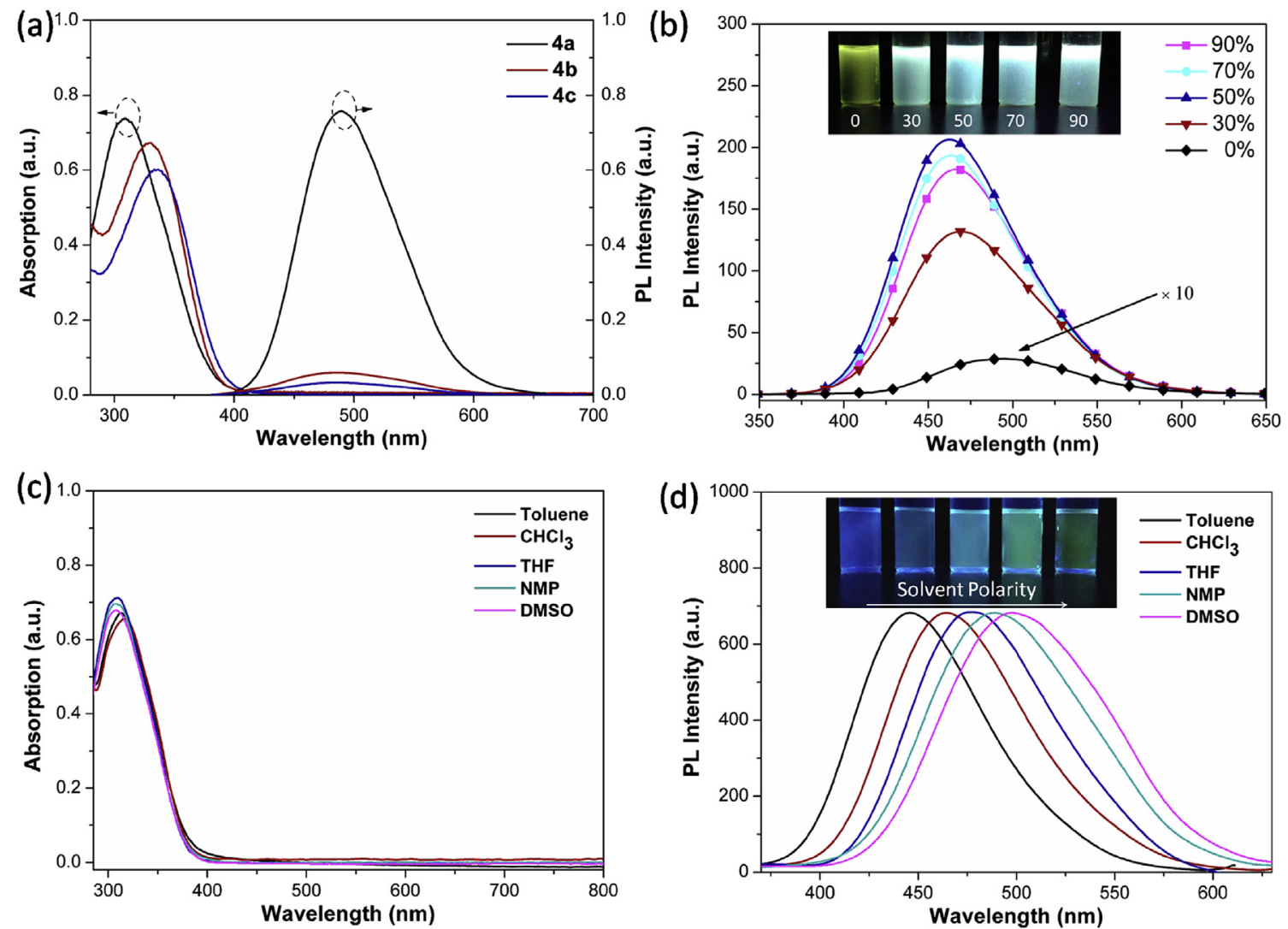

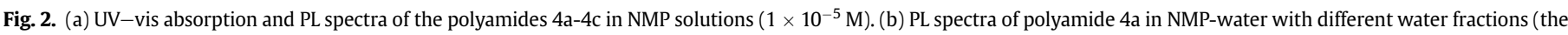

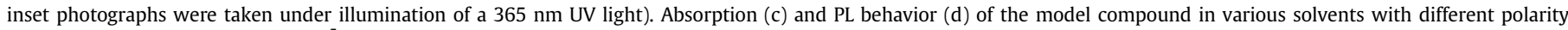
(solution concentration was $1 \times 10^{-5} \mathrm{M}$ and the inset photographs were taken under illumination of a $365 \mathrm{~nm}$ UV light.

(a)

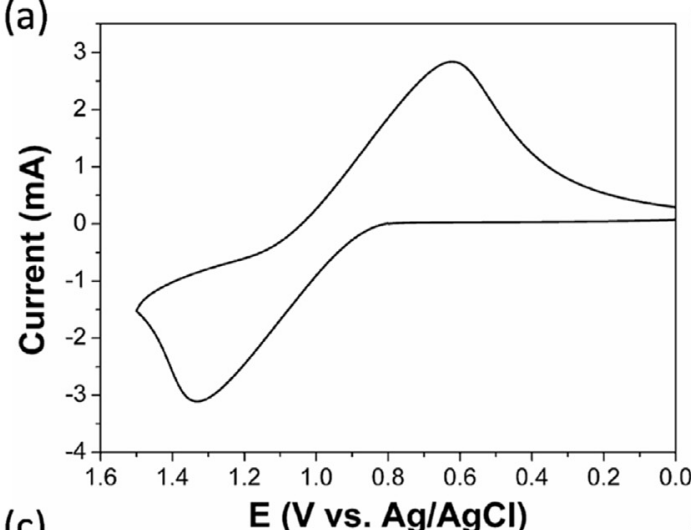

(c)

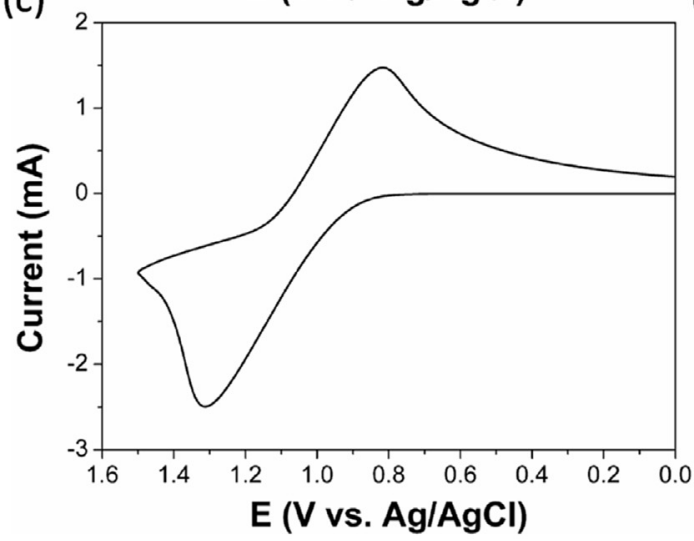

(b)

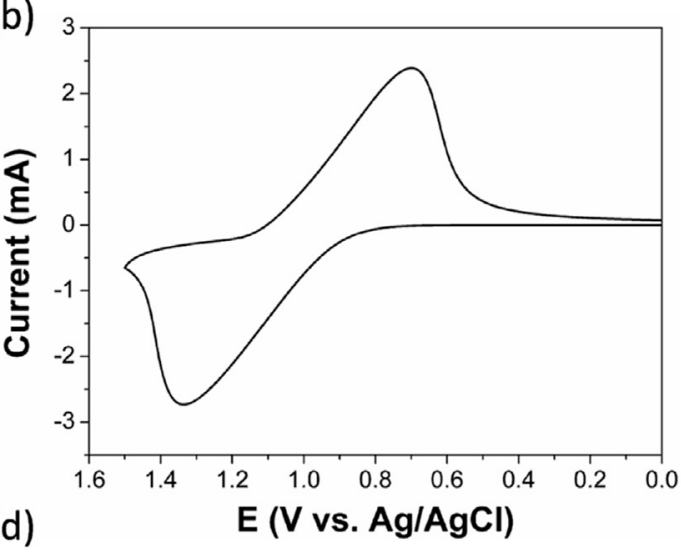

(d)

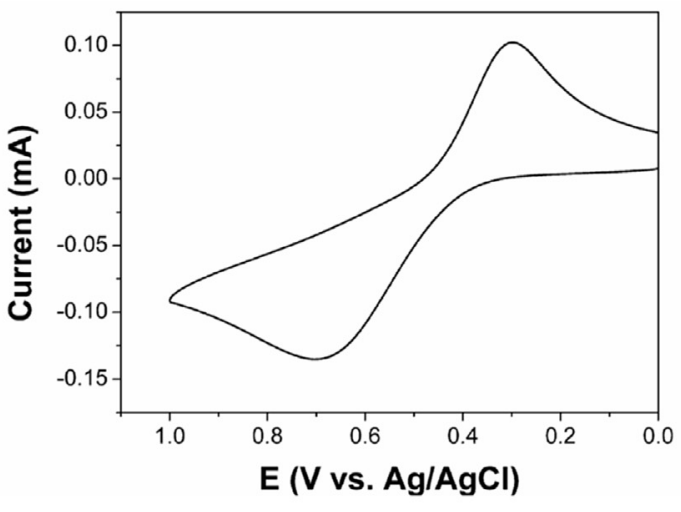

Fig. 3. Cyclic voltammetric diagrams of the polymers (a) 4a, (b) $4 \mathrm{~b}$, (c) $4 c$, (d) ferrocene in $\mathrm{CH}_{3} \mathrm{CN}$ containing $0.1 \mathrm{M}$ TBAP at a scan rate of $100 \mathrm{mV} \mathrm{s}^{-1}$. 

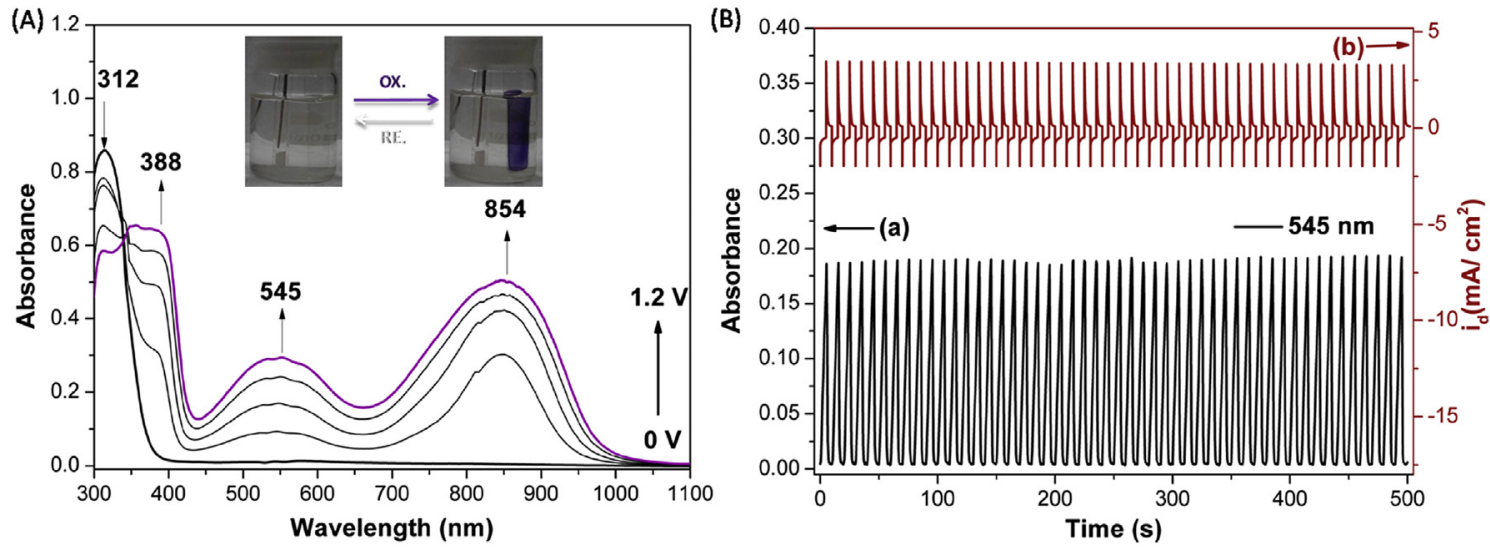

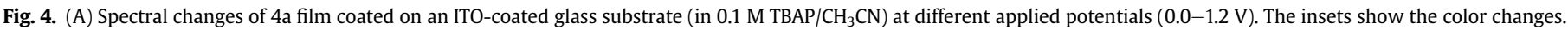

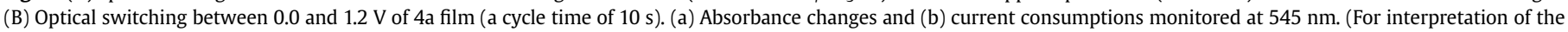
references to colour in this figure legend, the reader is referred to the web version of this article.)
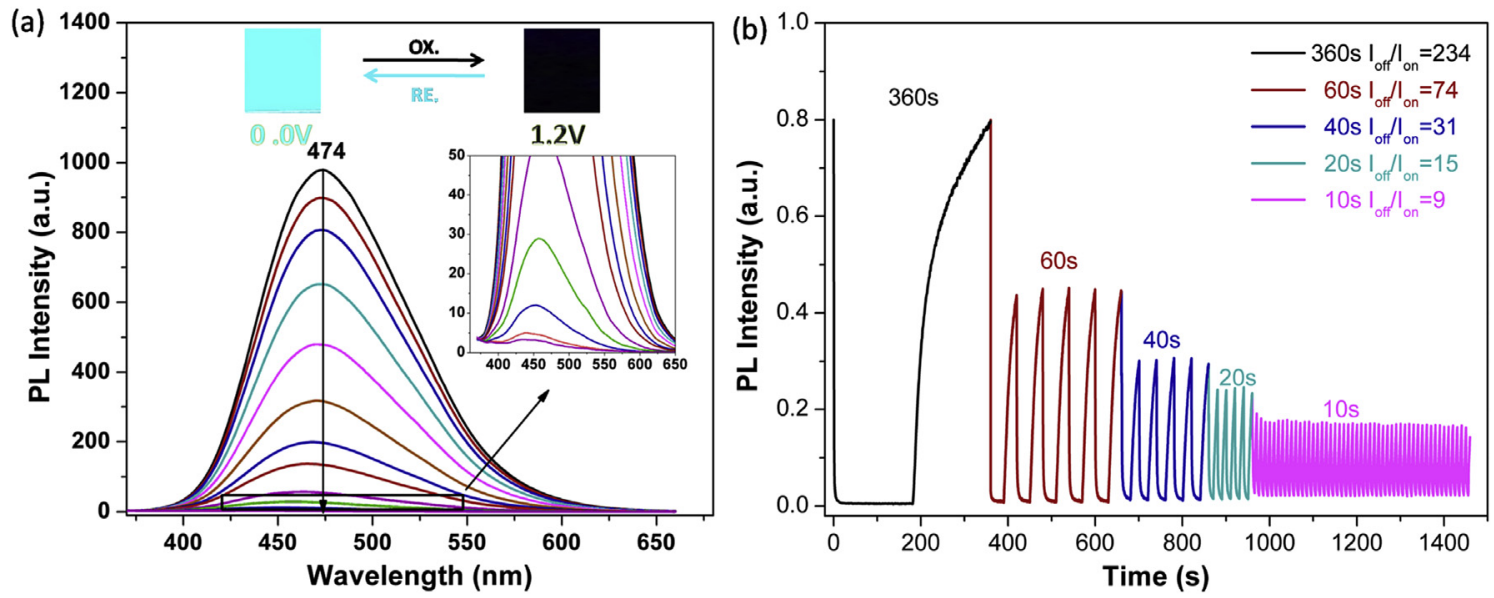

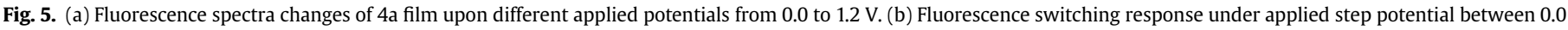
and $1.2 \mathrm{~V}$ with a step duration time for $360,60,40,20,10 \mathrm{~s}$ at each potential.

cycle to $113 \mathrm{~cm}^{2} \mathrm{C}^{-1}$ for the fiftieth cycle.

\subsection{Electrofluorochromic performance}

The polyamide 4a with methylsulfonyltriphenylamine exhibited shining fluorescence, especially in the solid state, but $\mathrm{TPA}^{+}$is known as an effective fluorescence quencher [13]. Therefore, the fluorescence changes under a series of positive potentials were recorded to demonstrate its electrofluorochromic switching properties. Upon excitation at $365 \mathrm{~nm}$, the neutral polyamide film exhibited vivid cyan fluorescence, while the strong fluorescence vanished to dark and the intensity of the fluorescence peak at $474 \mathrm{~nm}$ decreased under positive potentials. When applying reverse potentials, during which the $\mathrm{TPA}^{+}$was reduced to the neutral state, the fluorescence recovered, and notably, the electrofluorochromism offered a high contrast ratio $\left(I_{\mathrm{off}} / I_{\mathrm{on}}\right.$ : between neutral fluorescent state and oxidized non-fluorescent state) of 234. It is worth noting that no shift of spectral band was observed during the changes of the fluorescence intensity, which indicates that the fluorescence quenching originated from the electrochemical oxidizing of the polyamide $4 \mathrm{a}$ to its cation radical form without other side reactions. Furthermore, the dynamic response behavior was also examined by repeating oxidation and reduction steps between $0.0 \mathrm{~V}$ and $1.2 \mathrm{~V}$ (Fig. 5b), which revealed excellent reversibility during the fluorescence "off/on" process. The contrast ratio exhibited dependent behavior on the switching time, changing from 234 to 9 by reducing the switching time from 360 to $10 \mathrm{~s}$. In addition, the long-term durability of the electrofluorochromic polyamide was also studied. No obvious decay in either "on" or "off" state was observed in 50 continuous switches when the switching time was set as $10 \mathrm{~s}$. Considering the easy processability and excellent electrochromic/electrofluorochromic properties, the polyamide $4 \mathrm{a}$ hold great potential for practical intelligent applications in the future.

\section{Conclusion}

In summary, we have designed and synthesized a series of AEEactive polyamides with methylsulfonyltriphenylamine units, which exhibited excellent solubility and thermal stability. These polyamides exhibited reversible electroactive and favorable electrochromic properties with color changing from colorless to purple. Notably, the polyamide 4a displayed an AEE feature with a high solid-state fluorescent quantum yield up to $32.1 \%$, and the strong fluorescence could be effectively modulated by electrochemical switching with a high contrast of 234 . Thus, the durable and highcontrast electrochromic/electrofluorochromic polyamide 4a will provide useful information for developing bifunctional displays or 
other electro-switching devices.

\section{Appendix A. Supplementary data}

Supplementary data related to this article can be found at http:// dx.doi.org/10.1016/j.dyepig.2017.01.078.

\section{References}

[1] Linde SVD, Sauer M. How to switch a fluorophore: from undesired blinking to controlled photoswitching. Chem Soc Rev 2014;43:1076-87.

[2] You J, Kim J, Park T, Kim B, Kim E. Highly fluorescent conjugated polyelectrolyte nanostructures: synthesis, self-assembly, and $\mathrm{Al} 3+$ ion sensing. Adv Funct Mater 2012;22:1417-24.

[3] Seo S, Pascal S, Park C, Shin K, Yang X, Maury O, Sarwade BD, et al. NIR electrochemical fluorescence switching from polymethine dyes. Chem Sci 2014;5:1538-44

[4] Ding GQ, Zhou H, Xu JW, Lu XH. Electrofluorochromic detection of cyanide anions using a benzothiadiazole-containing conjugated copolymer. Chem Commun 2014;50:655-7.

[5] Audebert P, Miomandre F. Electrofluorochromism: from molecular systems to set-up and display. Chem Sci 2013:4:575-84.

[6] Sun JW, Chen YN, Liang ZQ. Electroluminochromic materials and devices. Adv Funct Mater 2016;26:2783-99.

[7] Al-Kutubi H, Zafarani HR, Rassaei L, Mathwig K. Electrofluorochromic systems: Molecules and materials exhibiting redox-switchable fluorescence. Eur. Polym. J 2016;83:478-98.

[8] Jin LH, Fang YX, Hu P, Zhai YL, Wang EK, Dong SJ. Polyoxometalate-based inorganic-organic hybrid film structure with reversible electroswitchable fluorescence property. Chem Commun 2012;48:2101-3.

[9] Kuo CP, Lin YS, Leung MK. Electrochemical fluorescence switching properties of conjugated polymers composed of triphenylamine, fluorene, and cyclic urea moieties. J Polym Sci Part A Polym Chem 2012;50:5068-78.

[10] Seo S, Kim Y, Zhou Q, Clavier G, Audebert P, Kim E. White electrofluorescence switching from electrochemically convertible yellow fluorescent dyad. Adv Funct Mater 2012;22:3556-61.

[11] Yen HJ, Liou GS. Flexible electrofluorochromic devices with the highest contrast ratio based on aggregation-enhanced emission (AEE)-active cyanotriphenylamine-based polymers. Chem Commun 2013;49:9797-9.

[12] Quinton C, Rizzo VA, Verdes CD, Miomandre F, Clavier G, Audebert P. Redoxand protonation-induced fluorescence switch in a new triphenylamine with six stable active or non-active forms. Chem Eur J 2015;21:2230-40.

[13] Sun JW, Liang ZO. Electrofluorochromism of donor-acceptor conjugated polytriphenylamines. ACS Appl Mater Interfaces 2016;8:18301-8.

[14] Mishra A, Fischer MKR, Bauerle P. Metal-free organic dyes for dye-sensitized solar cells: from structure: property relationships to design rules. Angew Chem Int Ed 2009;48:2474-99.

[15] Cias P, Slugovc C, Gescheidt G. Hole transport in triphenylamine based OLED devices: from theoretical modeling to properties prediction. J Phys Chem A 2011:115:14519-25.

[16] Zhang G, Bala H, Cheng Y, Shi D, Lv X, Yu Q et al. High efficiency and stable dye-sensitized solar cells with an organic chromophore featuring a binary $\pi$ conjugated spacer. Chem Commun 2009;16:2198-200.

[17] Kurosawa T, Higashihara T, Ueda M. Polyimide memory: a pithy guideline for future applications. Polym Chem 2013;4:16-30.

[18] Yen HJ, Liou GS. Solution-processable triarylamine-based high-performance polymers for resistive switching memory devices. Polym J 2016:48:117-38.

[19] Tsai CL, Lee TM, Liou GS. Novel solution-processable functional polyimide/ZrO 2 hybrids with tunable digital memory behaviors. Polym Chem 2016;7: 4873-80.

[20] Yen HJ, Liou GS. Solution-processable triarylamine-based electroactive high performance polymers for anodically electrochromic applications. Polym Chem 2012;3:255-64.
[21] Weng D, Shi YC, Zheng JM, Xu CY. High performance black-to-transmissive electrochromic device with panchromatic absorption based on TiO 2 supported viologen and triphenylamine derivatives. Org Electron 2016;34: 139-45.

[22] Lai JC, Lu XR, Qu BT, Liu F, Li CH, You XZ. A new multicolored and near-infrared electrochromic material based on triphenylamine-containing poly (3, 4dithienylpyrrole). Org Electron 2014;15:3735-45.

[23] Ji Y, Zhang CY, Niu HJ, Zhao XF, Wang C, Qin CL, et al. Preparation and electrochromic properties of two series of polyurethanes containing separated triphenylamine moiety with different blocks. Dyes Pigm 2016;125:106-15.

[24] Yen HJ, Lin HY, Liou GS. Novel starburst triarylamine-containing electroactive aramids with highly stable electrochromism in near-infrared and visible light regions. Chem Mater 2011;23:1874-82.

[25] Yen HJ, Chen CJ, Liou GS. Flexible multi-colored electrochromic and volatile polymer memory devices derived from starburst triarylamine-based electroactive polyimide. Adv Funct Mater 2013;23:5307-16.

[26] Hagopian L, Kohler G, Walter RI. Substituent effects on the properties of stable aromatic free radicals. Oxidation-reduction potentials of triaryl-aminetriarylaminium ion systems. J Phys Chem 1967;71:2290-6.

[27] Chang CW, Liou GS, Hsiao SH. Highly stable anodic green electrochromic aromatic polyamides: synthesis and electrochromic properties. J Mater Chem 2007; 17:1007-15.

28] Sun NW, Feng F, Wang DM, Zhou ZW, Guan Y, Dang GD, et al. Novel polyamides with fluorene-based triphenylamine: electrofluorescence and electrochromic properties. RSC Adv 2015;5:88181-90.

[29] Quinton C, Rizzo VA, Verdes CD, Miomandre F, Clavier G, Audebert P, et al Redox-and protonation-induced fluorescence switch in a new triphenylamine with six stable active or non-active forms. Chem Eur J 2015;21:2230-40.

[30] Kuo CP, You SL, Man KL. Electrochemical fluorescence switching properties of conjugated polymers composed of triphenylamine, fluorene, and cyclic urea moieties. J Polym Sci, Part A Polym Chem 2012;50:5068-78.

[31] Tang BZ, Zhan XW, Yu G, Lee PPS, Liu YQ, Zhu DB. Efficient blue emission from siloles. J Mater Chem 2001;11:2974-8.

[32] Christensen PR, Nagle JK, Bhatti A, Wolf MO, Enhanced photoluminescence of sulfur-bridged organic chromophores. J Am Chem Soc 2013;135:8109-12.

[33] Hsiao SH, Wu LC. Fluorescent and electrochromic polymers from 2, 8-d (carbazol-9-yl) dibenzothiophene and its S, S-dioxide derivative. Dyes Pigm 2016;34:51-63.

[34] Zhang QS, Li J, Shizu K, Huang SP, Hirata S, Miyazaki H, et al. Design of efficien thermally activated delayed fluorescence materials for pure blue organic light emitting diodes. J Am Chem Soc 2012;134:14706-9.

[35] Wu SH, Aonuma M, Zhang QS, Huang SP, Nakagawa T, Kuwabara K, et al High-efficiency deep-blue organic light-emitting diodes based on a thermally activated delayed fluorescence emitter. J Mater Chem C 2014;2:421-4.

[36] Liu M, Seino Y, Chen DC, Inomata Su, Su SJ, Sasabe H, et al. Blue thermally activated delayed fluorescence materials based on bis (phenylsulfonyl) benzene derivatives. Chem Comm 2015;51:16353-6.

[37] Wang $H$, Xie LS, Peng $\mathrm{O}$ Meng LO Wang Y, Yi YP, et al. Novel thermally activated delayed fluorescence materials-thioxanthone derivatives and their applications for highly efficient OLEDs. Adv Mater 2014;26:5198-204.

[38] Zheng CJ, Wang J, Ye J, Lo MF, Liu XK, Fung MK, et al. Novel efficient blue fluorophors with small singlet-triplet splitting: hosts for highly efficient fluorescence and phosphorescence hybrid WOLEDs with simplified structure. Adv Mater 2013;25:2205-11.

[39] Ye J, Chen Z, Fung MK, Zheng CJ, Ou XM, Zhang XH, et al. Carbazole/sulfone hybrid D- $\pi$-A-structured bipolar fluorophores for high-efficiency blue-violet electroluminescence. Chem Mater 2013;25:2630-7.

[40] Yamazaki N, Higashi F, Kawabata J. Studies on reactions of the N-phosphonium salts of pyridines. XI. Preparation of polypeptides and polyamides by means of triaryl phosphites in pyridine. J Polym Sci Polym Chem Ed 1974;12: 2149-54.

[41] Mei J, Leung NLC, Kwok RTK, Lan JWY, Tang BZ. Aggregation-induced emission: together we shine, united we soar. Chem Rev 2015;115:11718-940.

[42] Reichardt C. Solvatochromic dyes as solvent polarity indicators. Chem Rev 1994:94:2319-58. 